\title{
Impact and Extent of Participation of Women and Rural Youth in Skill Development Training Programme on Mushroom Cultivation Imparted by Cooch Behar KVK
}

\author{
Biman Maity*, Tarun Kumar Das and Kausik Pradhan \\ Department of Agricultural Extension, Uttar Banga Krishi Viswavidyalaya, \\ Pundibari, Cooch Behar, West Bengal-736165, India \\ *Corresponding author
}

\begin{tabular}{|l|}
\hline Ke y w o r d s \\
$\begin{array}{l}\text { Impact, Skill } \\
\text { development, Rural } \\
\text { youth, Rural women, } \\
\text { Mushroom cultivation }\end{array}$ \\
\hline Article Info \\
\hline $\begin{array}{l}\text { Accepted: } \\
\text { 12 July 2019 } \\
\text { Available Online: } \\
\text { 10 August } 2019\end{array}$ \\
\hline
\end{tabular}

\section{Introduction}

Skill development is the instrumental for primary off farm agriculture and allied income generation enterprise. Among the different off farm income generation enterprises, the mushroom production plays a crucial role in case of enhancing the income of the farming
Skill development is the instrumental for primary off farm agriculture and allied income generation enterprise. Among the different off farm income generation enterprises, the mushroom production plays a crutial role in case of enhancing the income of the farming community. It is a profitable business for the farm women and rural youth now a day. In different corners of Cooch Behar district, the women and rural farm youth are getting their employment and augment their earning through mushroom production and there is very good demand in the market of it. The Cooch Behar KVK is organizing different skill development training programmes for the farm women and farm youth in agriculture and allied sectors. The mushroom production and marketing training programme is one of them. Mushroom production was started in the 18th century. At present, the world's total edible and medicinal mushrooms production was estimated at over 34 million tons. China is the main producer of mushrooms producing over 30 million tons. This is accounted for about $87 \%$ of total production. In India, oyster mushroom have become the most popular for commercial production in recent years. India produced 129782 metric ton of mushroom in the year 2016(ICAR-DMR, Solan official data). The study was conducted at Cooch Behar district of West Bengal as the Cooch Behar KVK is acting as a single window system for imparting vocational training on mushroom cultivation. The purposive and random sampling procedures were followed to select the farm women and farm youth for the present study as respondents. The result shows that rural women are more involved in mushroom cultivation than rural youth. Most of the respondents participate in vocational training of mushroom cultivation to adopt mushroom cultivation as an enterprise. The impact shows use of locally available resources for production of different species of mushroom cultivation increased. It is shown that SHG groups get more profit than the individual enterprise. Mushroom growing is such an enterprise in which requirement of land is not a big issue so even landless farmers can augment their income through mushroom cultivation. The farm women and rural youth of the villages were surprised with the success of mushroom cultivation. They could not just believe such a good amount of net profit of ₹ 2500 to ₹ 3000 per month can be obtained with minimum investment. The study clearly indicates that imparting good numbers of skill based training programme with proper follow-up activities will help farm women and rural youth in employment generation and improve the livelihood of the farm family. 
marketing of it. It is a well- established fact that the rural unemployed individuals specially the farm women and rural youth can be developed their outlook through this enterprises with locally available resources by availing skill oriented training programme from the KVK, SAU or other agency. The Cooch Behar KVK is organizing different training programme for building capacity and skill of the farm women and farm youth in different off farm agriculture and allied vocations for sustained of their livelihood. The mushroom production and marketing training programme is one of them.

Mushroom production was started in the 18th century. At present, the world's total edible and medicinal mushrooms production was estimated at over 34 million tons. China is the main producer of mushrooms producing over 30 million tons. This is accounted for about $87 \%$ of total production. In India, oyster mushroom has become the most popular for commercial production in recent years. India produced 129782 metric ton of mushroom in the year 2016 (ICAR-DMR, Solan official data).

Mushroom is not only rich source for nutritious protein, it is also effectively used in the production of highly effective medicinal products. They provide high quality fats and low in carbohydrates and cholesterol, which is ideal for reducing body weight (Qumio et al., 1990). The demand of mushroom has been increasing day by day due to population growth, market expansions, changing of consumer education and awareness along with the developments in the manufacturing industries, storage facilities, and transportation. Mushroom cultivation can help reduce vulnerability to poverty and strengthens livelihoods through the generation of a fast yielding and nutritious source of food and a reliable source of income (Rachna et al., 2013).
In such a situation the present study has been conducted with an aim to assess the impact and extent of participation of women and rural youth in skill development programme on mushroom cultivation imparted by Cooch Behar KVK. It has been operationalized and conceptualized through identifying the reasons for participation in training programme, impact of skill development training programme and the trend of increasing profit by applying the skill.

\section{Materials and Methods}

The study was conducted at Cooch Behar district of West Bengal as the Cooch Behar $\mathrm{KVK}$ is acting as a single window system for imparting vocational training on mushroom cultivation. The purposive and random sampling procedures were followed to select the farm women and farm youth for the present study as respondents. An exhaustive list was prepared of farm women and farm youth who have participated in vocational training programme on mushroom cultivation with the help of Cooch Behar KVK professionals. From this list 60 no. of farm women and farm youth were selected randomly for the present study as respondents. Data were collected with the help of semi structured interview schedule through personal interview and Focused Group Discussion (FGD) method to generate primary and secondary information related to the study. The collected data were analyzed with the help of statistical tools like frequency, percentage. The data were interpreted in graphical and tabular form.

\section{Results and Discussion}

The table 1 shows that total nos. of respondents is 60 , out if which number of rural youth is 25 and rural women is 35 . The maximum number of respondents is of middle age group and their age ranged between 26 
and 40. 46.67 per cent of respondent have middle level of landholding capacity. 28.33 per cent of the respondents had upper primary level of education status.53.33 per cent of the respondents' main occupation is farming.

This table 2 shows that 78.33 per cent of respondents selected these enterprises 'to adopt mushroom production as an enterprise. The second reason is 'As a secondary income generation activity using locally available resources i.e. paddy straw, wheat, husk etc.' as reported by 66.6 per cent of respondents.

The third reason is 'To get certificate of vocational training course for financial assistance' as respond by 40.0 per cent of respondents followed by the last reason is 'To learn about mushroom growing techniques for self- consumption' as reported by 21.67per cent of respondents.

This table 3 shows that 78.33 per cent of respondent said the main impact of skilled training programme on mushroom cultivation is 'Use of locally available resources for production of different species of mushroom cultivation followed by 33.33 per cent reported on the less impact is on Value addition in harvest mushroom/ sell of dry mushroom.

In this table 4 shows that in case of individual trainees, they at a time produce 75-100 cylinder once and they repeated it three times in a year. The production cost of one cylinder is ₹ 25.00 and the total production cost varies from ₹ 6875.00-₹7500.00 and they sell mushroom ₹ $50.00 / \mathrm{kg}$.

From one cylinder they can produce $1 \mathrm{~kg}$ to $1.25 \mathrm{~kg}$ raw mushroom. After selling total mushroom they earned ₹ 16500.00₹ 18000.00 as grossed income and ₹ 9625.00₹ 10500.00 as net profit.
In case of SHG/ Farmers Club they at a time produce 225-250 cylinder and they repeated it three times in a year.

The production cost of one cylinder is ₹ 25.00 and the total production cost varies from ₹ 16875.00-₹ 18750.00 and they sell the mushroom of $₹ 50.00 / \mathrm{kg}$. From one cylinder they can produce $1 \mathrm{~kg}$ to $1.25 \mathrm{~kg}$ raw mushroom.

After selling total mushroom they obtained gross income of ₹ 23625.00- ₹ 26250.00 and net profit of₹ 23625.00- ₹ 26250.00.

The table 5 shows that in case of individual trainees, in the initial stage they earned profit ₹ 5500.00-₹ 6000.00 and after six month of training they earned of ₹ 9500.00-₹ 10000.00.

In case of SHG/Farmers Club trainees, at the initial stage of they get profit ₹ 18000.00 $₹ 20000.00$ and after six month they earned of ₹ 24000.00-₹ 25000.00.

Mushroom growing is such an enterprise in which requirement of land is not a big issue so even landless farmers can augment their income through mushroom cultivation.

The farm women and rural youth of the villages were surprised with the success of mushroom cultivation.

They could not just believe such a good amount of net profit of ₹ 2500.00 to ₹ 3000.00 per month can be obtained with minimum investment.

The study clearly indicates that imparting good numbers of skill based training programme with proper follow-up activities will help farm women and rural youth will help in employment generation and improve the livelihood of the farm family (Fig. 1-4). 
Table.1 Socio economic status of the respondents participating in vocational training programme on mushroom cultivation

\begin{tabular}{|c|c|c|c|}
\hline & & & $\mathrm{N}=60$ \\
\hline Sl. No. & Particulars & Frequency & Percentage \\
\hline \multirow[t]{3}{*}{1.} & \multicolumn{3}{|l|}{ Participant } \\
\hline & Rural Youth & 25 & 41.67 \\
\hline & Rural Women & 35 & 58.33 \\
\hline \multirow[t]{4}{*}{2.} & \multicolumn{3}{|l|}{ Age } \\
\hline & Upto -25 & 14 & 23.33 \\
\hline & $26-40$ & 32 & 53.33 \\
\hline & Above 40 & 4 & 6.67 \\
\hline \multirow[t]{4}{*}{3.} & \multicolumn{3}{|l|}{ Landholding (in bigha) } \\
\hline & Marginal (upto 1 bigha) & 22 & 36.67 \\
\hline & Medium (1-2 bigha) & 28 & 46.67 \\
\hline & Big (Above 2 bigha) & 10 & 16.66 \\
\hline \multirow[t]{6}{*}{4.} & \multicolumn{3}{|l|}{ Education } \\
\hline & Primary & 12 & 20.00 \\
\hline & Upper-Primary & 17 & 28.33 \\
\hline & Madhyamik & 13 & 21.67 \\
\hline & Higher Secondary & 12 & 20.00 \\
\hline & Graduate and Above & 6 & 10.00 \\
\hline \multirow[t]{5}{*}{5.} & \multicolumn{3}{|l|}{ Occupation } \\
\hline & Farming & 32 & 53.33 \\
\hline & Business & 8 & 13.33 \\
\hline & Housewife & 15 & 25.00 \\
\hline & Labour & 5 & 8.33 \\
\hline
\end{tabular}

Table. 2 Reasons for participation in vocational training programme on mushroom cultivation: $\mathrm{n}$ $=60(n=$ Number of respondent $)$

\begin{tabular}{|c|l|c|c|}
\hline Sl. No. & \multicolumn{1}{|c|}{ Reasons } & Frequency & Percentage \\
\hline $\mathbf{1 .}$ & $\begin{array}{l}\text { To learn about mushroom growing techniques for } \\
\text { self- consumption }\end{array}$ & 13 & 21.67 \\
\hline $\mathbf{2 .}$ & $\begin{array}{l}\text { To get certificate of vocational training course for } \\
\text { financial assistance }\end{array}$ & 24 & 40.00 \\
\hline $\mathbf{3 .}$ & To adopt mushroom production as an enterprise & 47 & 78.33 \\
\hline $\mathbf{4 .}$ & $\begin{array}{l}\text { As a secondary income generation activity using } \\
\text { locally available resources i.e. paddy straw, wheat } \\
\text { husk etc. }\end{array}$ & 40 & 66.67 \\
\hline
\end{tabular}


Table.3 Impact of skilled training programme on Mushroom Cultivation: $n=60$ ( $n=$ Number of respondent)

\begin{tabular}{|c|l|c|c|}
\hline Sl. No. & \multicolumn{1}{|c|}{ Impact } & Frequency & Percentage \\
\hline 1. & $\begin{array}{l}\text { Knowledge embedded skill on } \\
\text { identification of cultivated and wild } \\
\text { edible mushroom }\end{array}$ & 40 & 66.67 \\
\hline 2. & $\begin{array}{l}\text { Use of locally available resources for } \\
\text { production of different species of } \\
\text { mushroom cultivation }\end{array}$ & 47 & 78.33 \\
\hline 3. & $\begin{array}{l}\text { Bi-product of mushroom cultivation } \\
\text { are used as compost making }\end{array}$ & 45 & 700 \\
\hline 4. & $\begin{array}{l}\text { Good scientific knowledge in } \\
\text { management of pest and disease in } \\
\text { mushroom production }\end{array}$ & 42 & 7000 \\
\hline 5. & $\begin{array}{l}\text { Value addition in harvest mushroom/ } \\
\text { sell of dry mushroom }\end{array}$ & 20 & 33.33 \\
\hline
\end{tabular}

Table.4 Profit realised by the farm women and farm youth through mushroom cultivation

\begin{tabular}{|c|c|c|c|c|}
\hline Trainees & $\begin{array}{c}\text { No. of Cylinder } \\
\text { Prepared in a } \\
\text { session }\end{array}$ & $\begin{array}{c}\text { Cost of } \\
\text { Cultivation } \\
\text { (₹ 25/ cylinder) }\end{array}$ & $\begin{array}{c}\text { Total income } \\
\text { (₹ ) }\end{array}$ & $\begin{array}{l}\text { Profit } \\
\text { (₹ ) }\end{array}$ \\
\hline Individual & $\begin{array}{l}(75-100) * 3= \\
275-300\end{array}$ & $6875.00-7500.00$ & $\begin{array}{l}16500.00- \\
18000.00\end{array}$ & $\begin{array}{l}9625.00- \\
10500.00\end{array}$ \\
\hline $\begin{array}{l}\text { SHG/Farmers } \\
\text { Club }\end{array}$ & $\begin{array}{l}(225-250)^{*} 3= \\
675-750\end{array}$ & $\begin{array}{l}16875.00- \\
18750.00\end{array}$ & $\begin{array}{l}40500.00- \\
45000.00\end{array}$ & $\begin{array}{l}23625.00- \\
26250.00\end{array}$ \\
\hline
\end{tabular}

Note: Raw mushroom sells at the rate of ₹ $50 / \mathrm{kg}$, one cylinder produced around $1-1.25 \mathrm{~kg}$ raw mushroom $*$ Number of times $=3$

Table.5 Difference between income at initial stage of training and six months after training

\begin{tabular}{|c|l|c|}
\hline \multicolumn{1}{|c|}{ Trainees } & \multicolumn{1}{|c|}{ Statement } & \multicolumn{1}{c|}{ Profit (₹) } \\
\hline \multicolumn{1}{|c|}{ Individual } & $\begin{array}{l}\text { Profit obtained in initial stage } \\
\text { after training programme }\end{array}$ & $5500.00-6000.00$ \\
\cline { 2 - 3 } & $\begin{array}{l}\text { Profit obtain after 6 month of } \\
\text { training }\end{array}$ & $9500.00-10000.00$ \\
\hline SHG/Farmers Club & $\begin{array}{l}\text { Profit obtained in initial stage } \\
\text { after training programme }\end{array}$ & $18000.00-20000.00$ \\
\hline & $\begin{array}{l}\text { Profit obtain after 6 month of } \\
\text { training }\end{array}$ & $24000.00-25000.00$ \\
\hline
\end{tabular}


Fig.1 Reasons for participation in vocational training programme on mushroom cultivation: $\mathrm{n}=60$

As a secondary income generation activity using locally available...

To adopt mushroom production as an enterprise

To learn about mushroom growing techniques for self- consumption

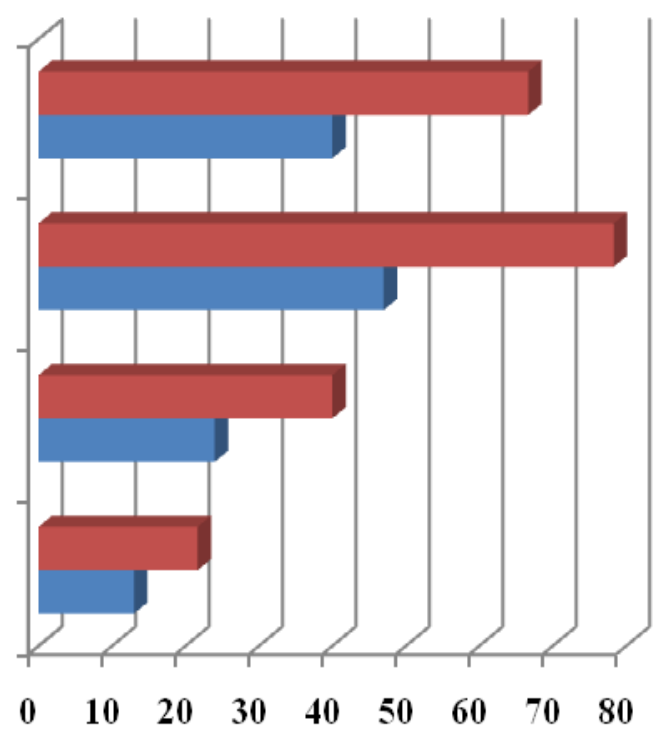

- Percentage

- Frequency

Fig.2 Graphical representation on impact of skilled training programme on Mushroom Cultivation: $n=60$

Value addition in harvest mushroom/ sell of dry mushroom

Good scientific knowledge in management of pest and disease in mushroom production

Bi-product of mushroom cultivation are used as compost making

Use of locally available resources for production of different species of...

Knowledge embedded skill on identification of cultivated and wild edible mushroom

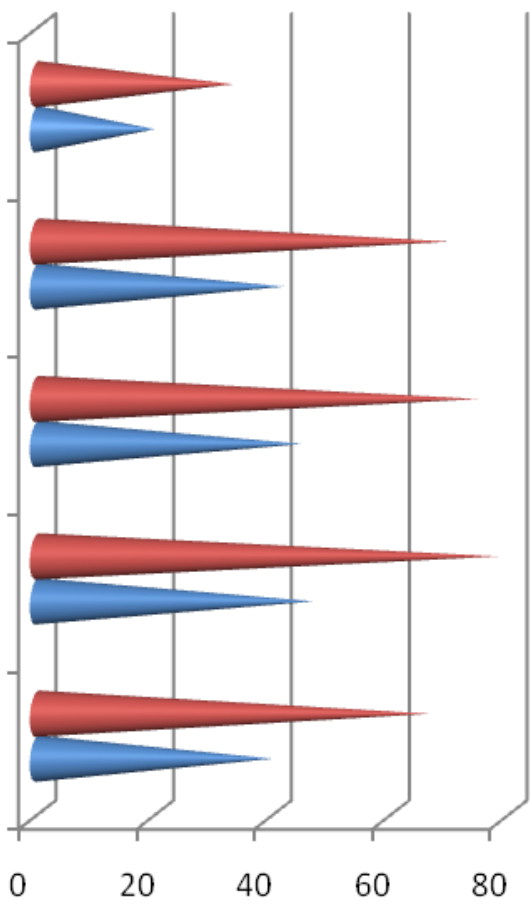

Percentage 
Fig.3 Increasing profit trend on mushroom cultivation (Individual)

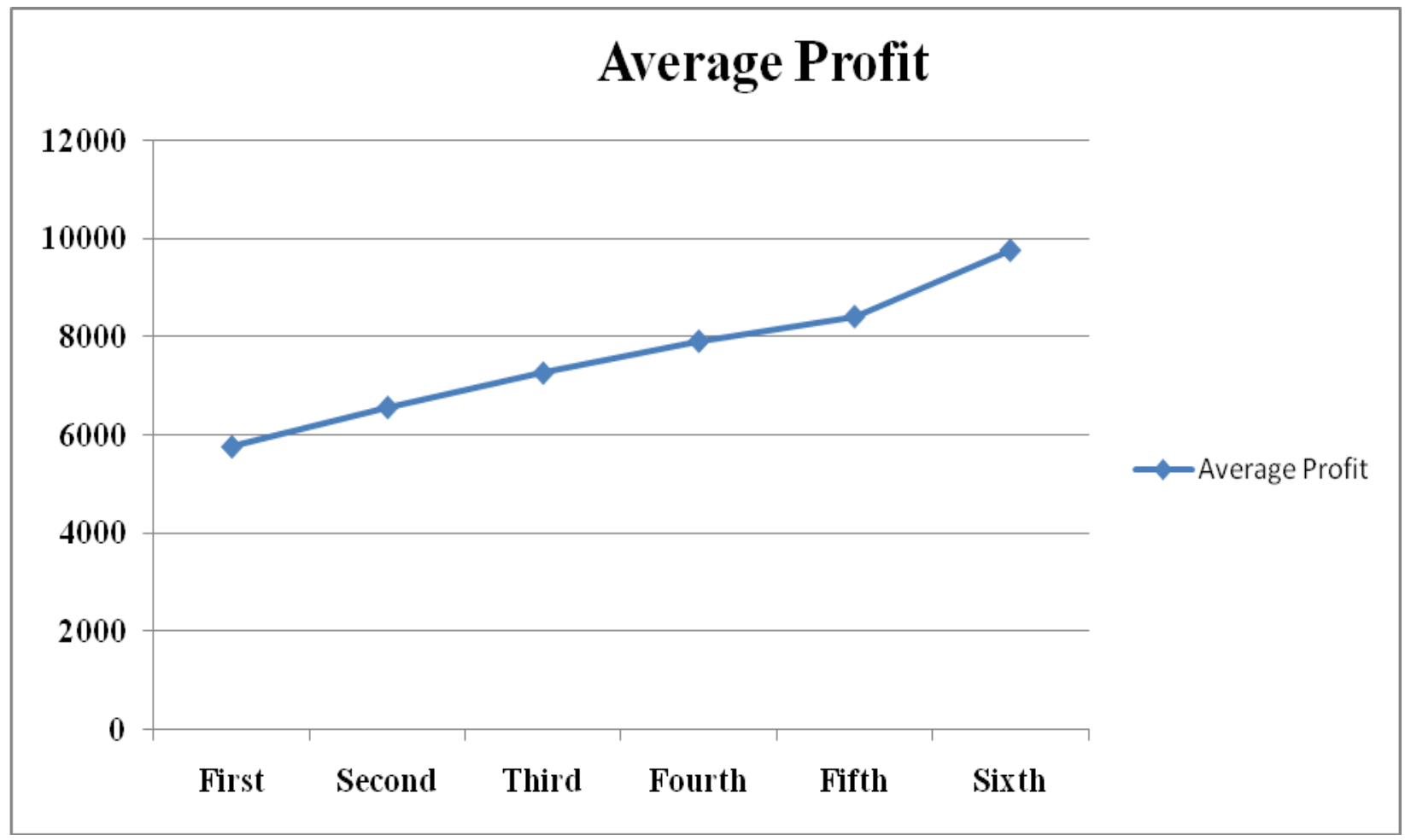

Fig.4 Increasing profit trend on mushroom cultivation (SHG/ Farmers Club)

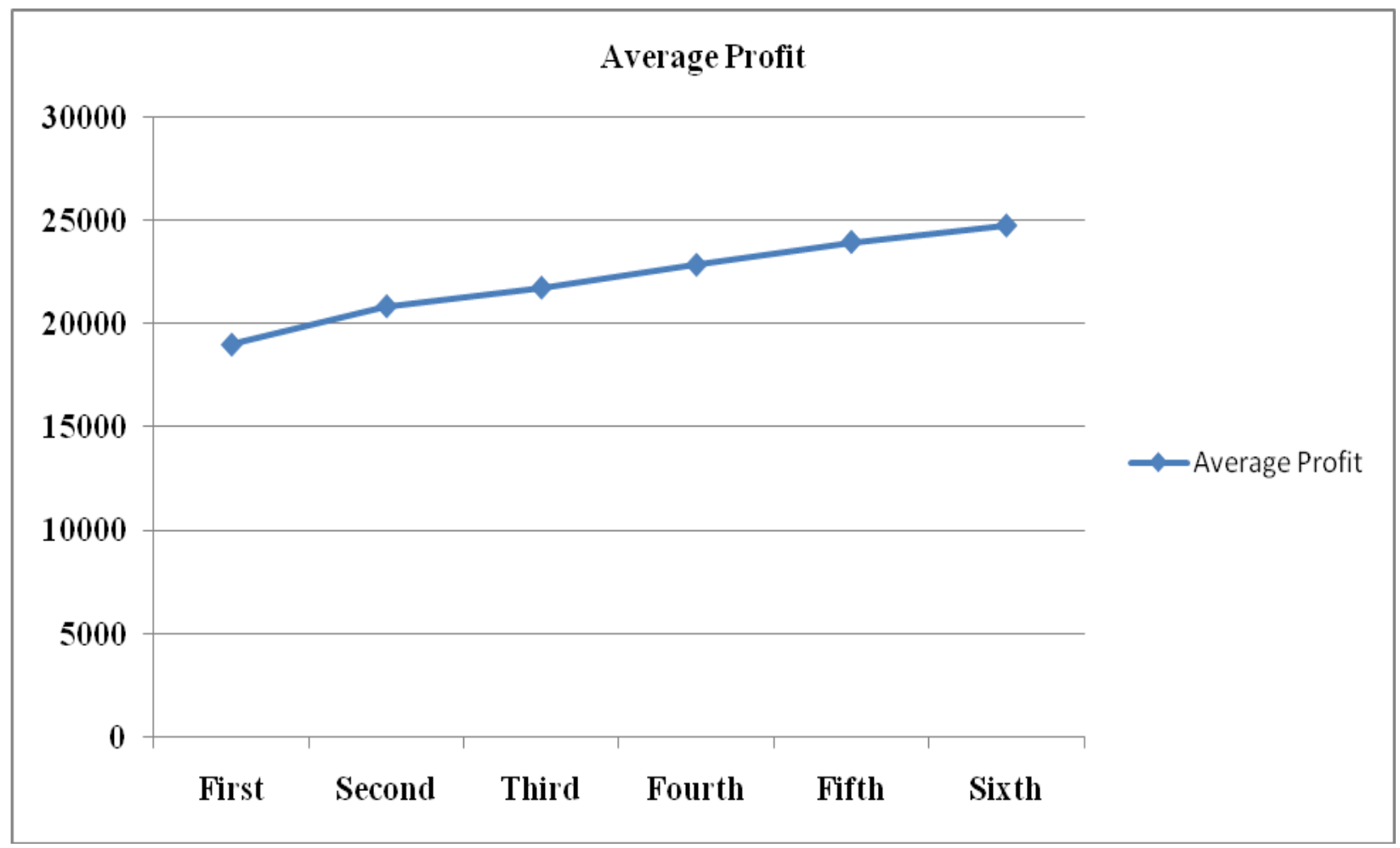




\section{Suggestion}

Line departments, KVKs, Universities, NGOs and Farmers club will focus on off farm income generating activities and impart skill oriented vocational training on need based and location specific issues with the help of locally available resources for the farm women and rural youth.

There is a need of proper follow-up and monitoring mechanism after imparting the training programme on off farm income generating avenues to sustain the impact at the grassroot level.

Marketing of agricultural produce is also important for sustainability of income generating avenues. The policy maker should think about the availability of market intelligence and development of appropriate value chain through a strong market linkage for sustainability of off farm income generating enterprise and empowerment of rural women and rural youth. In this regard there is a need of capacity building programme imparted by line departments, KVKs, Universities, NGOs.

\section{References}

Goel R. and Sodhi G.P.S. 2013. Evaluation of vocational training programmes organized on mushroom farming by Krishi Vigyan Kendra Patiala. Journal of Krishi Vigyan. 2(1): 26-29.

Kaur K. 2016. Impact of Training Course on Knowledge Gain of Mushroom Trainees, Journal of Krishi Vigyan. 4(2): 54-57.

Qumio J.H., Chang S.T. and Royse D.J. 1990. Technical guidlines for mushroom growing in the tropics.FAO Plant Production and Protection, 1990, 106. Rome Italy M-11.

Shahi V., Shahi B., Kumar V., Singh K.M. and Kumari P. 2018. Impact study on mushroom cultivation for micro entrepreneurship development and women Empowerment, Journal of Pharmacognosy and Phytochemistry. SP4: 01-04.

\section{How to cite this article:}

Biman Maity, Tarun Kumar Das and Kausik Pradhan. 2019. Impact and Extent of Participation of Women and Rural Youth in Skill Development Training Programme on Mushroom Cultivation Imparted by Cooch Behar KVK. Int.J.Curr.Microbiol.App.Sci. 8(08): 1519-1526. doi: https://doi.org/10.20546/ijcmas.2019.808.178 